University of Nebraska - Lincoln

DigitalCommons@University of Nebraska - Lincoln

Faculty Publications, Department of Psychology

Psychology, Department of

2002

Serotonin Transporter Promoter Polymorphism, Peripheral

Indexes of Serotonin Function, and Personality Measures in

Families with Alcoholism

\author{
Scott F. Stoltenberg \\ University of Nebraska-Lincoln, sstoltenberg2@unl.edu \\ Geoffrey R. Twitchell \\ University of California at Los Angeles \\ Gregory L. Hanna \\ University of Michigan \\ Edwin H. Cook \\ University of Chicago \\ Hiram E. Fitzgerald \\ Michigan State University \\ See next page for additional authors \\ Follow this and additional works at: https://digitalcommons.unl.edu/psychfacpub \\ Part of the Psychiatry and Psychology Commons
}

Stoltenberg, Scott F.; Twitchell, Geoffrey R.; Hanna, Gregory L.; Cook, Edwin H.; Fitzgerald, Hiram E.; Zucker, Robert A.; and Little, Karley Y., "Serotonin Transporter Promoter Polymorphism, Peripheral Indexes of Serotonin Function, and Personality Measures in Families with Alcoholism" (2002). Faculty Publications, Department of Psychology. 424.

https://digitalcommons.unl.edu/psychfacpub/424

This Article is brought to you for free and open access by the Psychology, Department of at DigitalCommons@University of Nebraska - Lincoln. It has been accepted for inclusion in Faculty Publications, Department of Psychology by an authorized administrator of DigitalCommons@University of Nebraska - Lincoln. 


\section{Authors}

Scott F. Stoltenberg, Geoffrey R. Twitchell, Gregory L. Hanna, Edwin H. Cook, Hiram E. Fitzgerald, Robert A. Zucker, and Karley Y. Little 


\title{
Serotonin Transporter Promoter Polymorphism, Peripheral Indexes of Serotonin Function, and Personality Measures in Families with Alcoholism
}

\author{
Scott F. Stoltenberg, ${ }^{1}$ Geoffrey R. Twitchell, ${ }^{2,3}$ Gregory L. Hanna, ${ }^{1}$ Edwin H. Cook, ${ }^{4}$ \\ Hiram E. Fitzgerald, ${ }^{2}$ Robert A. Zucker, ${ }^{1}$ and Karley Y. Little ${ }^{1}$ \\ 1 University of Michigan Addiction Research Center \& Department of Psychiatry, University of Michigan, Ann Arbor, Michigan \\ 2 Department of Psychology, Michigan State University, East Lansing, Michigan \\ 3 UCLA Integrated Substance Abuse Program, University of California at Los Angeles, Los Angeles, California \\ 4 Laboratory of Developmental Neuroscience \& Department of Psychiatry, University of Chicago, Chicago, Illinois \\ Corresponding author - Dr. Scott F. Stoltenberg
}

\begin{abstract}
A functional polymorphism in the regulatory region of the serotonin transporter gene (5-HTTLPR) is considered to be a plausible candidate gene for anxiety-related personality traits and for alcoholism. Empirical support for the association between 5-HTTLPR and psychological traits has been somewhat inconsistent; however, observations of the functional dominance of the low-activity s-allele over the l-allele have been more consistent. When studying the influence of particular genes on psychological traits, it seems useful also to assess more biological intermediate traits that may mediate the effects of those genes on the traits of interest. The present study examined relationships between 5-HTTLPR genotype, whole blood serotonin (5-HT) level, and platelet 5 -HT binding in 150 Caucasian subjects from 50 biological families. Individuals with the s-allele had lower average platelet 5-HT binding availability than those with the $1 / 1$ genotype $(P<0.025)$. Whole blood 5 -HT level was not associated with 5-HTTLPR genotype. In adult men, those with the s-allele had higher mean scores on the NEO-FFI personality trait of openness than did those with the $1 / 1$ genotype $(P=0.002)$. The effect was not statistically significant in women $(P=0.42)$, although it was in the same direction. Our findings do not support an association of 5-HTTLPR genotype with alcoholism diagnosis, alcoholism subtype, or the personality trait of
\end{abstract}

neuroticism. The results of this pilot study suggest that further work should examine the mediation of the genetic effects on personality traits by biochemical measures and their moderation by gender.

Keywords: association study, 5-HT, 5-HTTLPR, binding availability, openness, neuroticism

Perhaps the most promising candidate gene in psychiatric genetics is a variant in the promoter region of the serotonin transporter, called 5-HTTLPR [Heils et al., 1996, 1997; Lesch et al., 1996]. The two common alleles, short (s) and long (1), have functional differences in lymphocytes [Lesch et al., 1996], in blood platelets [Greenberg et al., 1999], and in brain [Little et al., 1998]. 5-HTTLPR is considered to be an important candidate to influence risk for psychiatric disorders [Stoltenberg and Burmeister, 2000], such as obsessive-compulsive disorder (OCD) [Hanna et al., 1998; Bengel et al., 1999], affective disorders [Collier et al., 1996], autism [Cook et al., 1997], and alcoholism [Sander et al., 1997; Edenberg et al., 1998; Hallikainen et al., 1999; Hammoumi et al., 1999; Ishiguro et al., 1999].

Associations between 5-HTTLPR and normal variation in personality traits, especially those related to anxiety, have been widely studied [Lesch et al., 1996; Mazzanti et al., 1998; Gustavsson et al., 1999; Greenberg et al., 2000]. The s-allele appears to be associated with higher scores on anxiety-related measures in some populations [Greenberg et al., 2000]. 
The present pilot study examines associations between 5-HTTLPR and indexes of 5-HT function (whole blood 5HT [WB-5-HT] and platelet 5-HT transporter binding) in families. In addition, associations between 5-HTTLPR genotype and personality traits measured by the NEO-Five Factor Inventory (NEO-FFI) [Costa and McCrae, 1992] are examined in adults. Finally, we compare allele frequencies in adult males grouped by alcoholism diagnosis and by alcoholism subtype.

The Michigan-Michigan State Longitudinal Study (MMSLS) [Zucker, 1987; Fitzgerald et al., 1995; Zucker et al., 1996, 1997] is following a population-based sample of children of alcoholics, both biological parents, and an ecologically comparable but nonalcoholic group of control families at 3-year intervals (i.e., Waves), beginning when the target boys were ages 3 to 5 and the target girls were between ages 3 and 11 [Zucker et al., 2000]. Alcoholism diagnosis was assessed using the Feighner diagnostic criteria [Feighner et al., 1972] within a structured clinical interview format [Robins et al., 1981].

Wave one involved 215 alcoholic and 96 nonalcoholic control families of primarily lower to lower-middle socioeconomic class and all of non-Hispanic Caucasian background. Inclusion criteria for the larger study included having a biological son between age 3 and 6 living in an intact family with both biological parents. Fetal alcohol syndrome in target children was exclusionary. Maternal alcoholism was neither inclusionary nor exclusionary for alcoholic families, although a subset of women married to antisocial alcoholic men (41\%) met lifetime DSM-III-R [American Psychiatric Association, 1987] alcohol abuse/ dependence diagnosis. Families were subtyped by paternal alcoholism and antisocial personality disorder diagnoses in earlier analytic work with the Longitudinal Study (antisocial alcoholism, nonantisocial alcoholism, nonalcoholic control) [Wong et al., 1999; Poon et al., 2000].

Subjects in the present study were 161 Caucasian biological family members from 50 families drawn from the MMSLS. These 50 families served as a pilot sample for initial examinations of biology and behavior relationships in association to alcoholism with reports from the children previously reported [Twitchell et al., 1998, 2000, 2001]. The basic family structure includes a male target child (MTC) and his biological father and mother ( $n=30$ families); some also included a female target child (FTC; $n=14$ ) and six were missing data from one or more members.

Medication screening, collection of demographic data, and blood sampling were performed by G.R.T. during an in-home session. Twenty-one-gauge needles were used in blood collection to ensure platelet integrity. Informed consent was obtained prior to data collection and the blood draw. At that time, the children ranged in age from 7 to 15 (45 boys, $11.05 \pm 1.82 ; 17$ girls, $10.43 \pm 2.50$ ). This protocol was approved by institutional review boards at the University of Michigan and Michigan State University. All subjects donated their blood samples and were paid for filling out questionnaires. Samples assayed for whole blood serotonin (WB-5-HT) were immediately transported to the laboratory and stored at $-70^{\circ} \mathrm{C}$ until the time of batch assay.
Blood samples used for platelet 5-HTT binding availability assay were immediately transported on ice to the laboratory for processing. Assays were performed blind to demographic and diagnostic information.

WB-5-HT assays and genotyping methods were described previously [Hanna et al., 1998]. WB-5-HT was analyzed by high-pressure liquid chromatography (HPLC) with fluorometric detection [Anderson et al., 1981]. 5-hydroxytryptophan was used as an internal standard. Infraassay and interassay coefficients of variation were $0.8 \%$ and $3.6 \%$, respectively.

Oligonucleotide primers flanking the HTT polymorphic regulatory region (stpr5, 5'-GGCGTTGCCGCTCTGAATTGC; stpr3, 5'-GAGGGACTGAGCTGGACAACCCAC) were used to generate a 484/528 bp fragment [Heils et al., 1996, 1997]. A second primer (HTTp2A, 5'-TGAATGCCAGCACCTAACCC-3'; HTT-p2B, 5'-TTCTGGTGCCACCTAGACGC-3') successfully amplified a 406/450 bp fragment from DNAs that failed to amplify with the first set. PCR was performed in a $10 \mu \mathrm{l} \mathrm{vol-}$ ume containing approximately $50 \mathrm{ng}$ of genomic template, $1 \mu \mathrm{M}$ of each primer, $200 \mu \mathrm{M}$ each dATP, dCTP, and dTTP, $100 \mu \mathrm{m}$ each of dGTP, and 7'-deaza-dGTP, 0.6 units of Taq polymerase (AmpliTaq; Perkin Elmer), $1.5 \mathrm{mM} \mathrm{MgCl}_{2}, 5 \%$ DMSO, $10 \mathrm{mM}$ Tris- $\mathrm{HCl}, 50 \mathrm{mM} \mathrm{KCl}$, and $0.001 \%$ gelatin. Samples were processed in a Perkin Elmer GeneAmp PCR System 9600 through 40 cycles of $30 \mathrm{sec}$ at $95^{\circ} \mathrm{C}, 30 \mathrm{sec}$ at $61^{\circ} \mathrm{C}$, and $1 \mathrm{~min}$ at $72^{\circ} \mathrm{C}$, followed by $10 \mathrm{~min}$ at $72^{\circ} \mathrm{C}$. PCR products were visualized on $4 \%$ agarose (Perkin Elmer) gels containing $0.5 \mu \mathrm{g} / \mathrm{mL}$ ethidium bromide.

The methods used to assay [ $\left.{ }^{125} \mathrm{I}\right] \mathrm{RTI}-55$ (also referred to as $\left.\left[{ }^{125} \mathrm{I}\right] \beta-\mathrm{CIT}\right)$ binding have been previously described [Little et al., 1993]. Briefly, the [125I]RTI-55 assay (specific activity 2,200 Ci/mmol; New England Nuclear/ Dupont) utilized a $0.32 \mathrm{M}$ sucrose and $10 \mu \mathrm{M} \mathrm{Na} \mathrm{HPO}_{4}$ buffer at $\mathrm{pH}$ 7.4. A saturating concentration of $\left[{ }^{125} \mathrm{I}\right]$ RTI-55 (3 nM, approximately $8 \times \mathrm{Kd}$ previously determined, $0.37 \mathrm{nM}$ ) was employed at equilibrium conditions $\left(1.5 \mathrm{hr}\right.$ at $\left.20^{\circ} \mathrm{C}\right)$. Incubations were performed with approximately $2 \mathrm{mg}$ of pelleted platelets, followed by rapid filtration over Whatman GF/B glass fiber filters presoaked in $0.01 \%$ polyethylenimine. Nonspecific binding was defined with $30 \mu \mathrm{M}(-) \mathrm{co}-$ caine. Specific binding averaged $90-95 \%$ of the total. Protein concentrations were determined using a commercial assay kit (BioRad, Claremont, CA).

Personality characteristics in the adults were assessed with the NEO-FFI [Costa and McCrae, 1992]. The NEO-FFI consists of 60 items (12 items per factor) and is designed to assess the five personality domains of neuroticism (negative affect), extraversion (sociability, assertiveness), openness (intellectual curiosity, unconventionality), agreeableness (altruism, sympathy), and conscientiousness (self-discipline, deliberation). Internal consistency coefficients for the NEO-FFI range from 0.68 to 0.86 for domain scales; validity is well established [Costa and McCrae, 1992].

For association analysis of WB-5-HT level and of $\left[{ }^{125} \mathrm{I}\right]$ RTI-55 binding, three models were tested: one additive (s/s, s/1, 1/1) and two dominance (sDom = s/s + 1/s vs. 1/ 1 , and 1 Dom $=\mathrm{s} / \mathrm{s}$ vs. $1 / \mathrm{s}+1 / \mathrm{l}$ ) using the ASSOC module of 
the Statistical Analysis for Genetic Epidemiology software package [SAGE, 1998].

General linear models (SPSS) were used to assess associations between 5-HTTLPR genotype and NEO-FFI scores. For fathers, we tested associations between 5-HTTLPR genotype, alcoholism diagnosis , and sub-type (antisocial alcoholic [AAL], nonantisocial alcoholic [NAAL], or nonalcoholic [control]) [Zucker et al., 1996; Puttier et al., 1998] with a case control design. Given the exploratory nature of these analyses, we were more willing to commit type I than type II errors; therefore, corrections for multiple testing were not performed.

Eleven subjects were excluded from all analyses because of medication use. Allele frequencies were calculated using only parental genotypes. The frequency of the 5-HTTLPR long allele 1 was 0.54 and the short allele s was $0.46(n=$ 86). Genotypes were in Hardy-Weinberg equilibrium (chisquare $=0.24,2 \mathrm{df}, \mathrm{NS}$ ).

Overall mean WB-5-HT level was $188.08 \pm 63.54 \mathrm{ng} /$ $\mathrm{ml},(n=150)$. [ $\left.{ }^{125} \mathrm{I}\right] \mathrm{RTI}-55$ binding was assayed for the final 54 samples collected. Mean [ $\left.{ }^{125} \mathrm{I}\right]$ RTI-55 binding level was $147.96 \pm 74.24 \mathrm{cpm} / \mathrm{mg}$ protein. Levels of WB-5-HT and [125I]RTI-55 binding were not correlated in parents $(r$ $=-0.01 ; P=0.96 ; n=33)$ or in children $(r=-0.29 ; P=0.20$; $n=21)$.

To control for age differences in WB-5-HT, we tested sex differences separately among men and women and among boys and girls. None were significant (all $P$ values $>0.17$ ); therefore, we did not control for age or sex in the SAGE analysis.

Model fit was assessed with the likelihood ratio statistic that is distributed as chi-square with degrees of freedom being 1 less than the number of genotype groups (e.g., 2 for additive and 1 for dominance models). For WB-5-HT, including marker data did not improve model fit, though the additive model fit best $(\mathrm{s} / \mathrm{s}=208.43,1 / \mathrm{s}=187.36,1 / 1=175.55$; chisquare $=4.10 ; P>0.10)$. Patterns of mean $\left[{ }^{125} \mathrm{I}\right] \mathrm{RTI}-55$ binding levels were consistent with the dominance of the s-allele (s/ $\mathrm{s}=138.50,1 / \mathrm{s}=133.31,1 / 1=190.15) ;$ accordingly, including sDom marker data improved model fit (chi-square $=5.19 ; P$ $<0.025$ ). Neither the IDom nor the additive marker data improved model fit (i.e., $P$ values $>0.05$ ).
Table I presents the mean raw NEO-FFI adult personality scores by genotype. One-way ANOVAs were used to test the effects of 5-HTTLPR on each of the personality measures. Only mean openness scores were significantly different for the genotype groups $(\mathrm{S}[\mathrm{s} / \mathrm{s}$ and $1 / \mathrm{s}]=38.34$, $\mathrm{L}[1 / 1]=34.54 ; \mathrm{F}=7.04 ; P=0.01$ ).

To examine the observed association further, we performed one-way ANOVAs separately for men and women. Among men, mean openness scores were different for the genotype groups $(\mathrm{S}=38.25, \mathrm{~L}=32.50 ; \mathrm{F}=10.60 ; P=0.002)$; among women, they were not $(\mathrm{S}=38.43, \mathrm{~L}=36.58 ; \mathrm{F}=0.68$; $P=0.42$ ). The effect of 5-HTTLPR on openness appears to be moderated by gender.

Father's genotype was not related to his alcoholism subtype (Fisher exact statistic $=2.24 ; P=0.73$; Table II). Similarly, when the genotype frequencies of those with any alcoholism diagnosis (AAL + NAAL) were compared to nonalcoholic controls, no relationship was observed (chisquare $=1.50,4 \mathrm{df}, P>0.75$ ).

Patterns in binding availability of the 5-HTT in blood platelets (indexed by [ $\left.{ }^{125} \mathrm{I}\right]$ RTI-55 binding) were consistent with the dominance of the s-allele for lower function. Levels of 5 -HTT binding in the L-group (1/1) were $42 \%$ higher than in the S-group $(1 / \mathrm{s}$ and $\mathrm{s} / \mathrm{s})$. This closely replicates the difference observed in lymphocyte membrane preparations reported by Lesch et al. [1996].

Levels of WB-5-HT were neither associated with 5-HTTLPR genotype nor correlated with platelet 5-HTT binding availability. WB-5-HT content likely reflects a number of different processes in addition to 5-HT uptake, so it is not surprising that WB-5-HT content and [125I]RTI-55 binding levels were not correlated. These results suggest that general statements about serotonergic dysfunction should be made cautiously.

In this study, we observed a difference in mean neuroticism scores of approximately $1 / 10$ of a point $(\mathrm{L}=28.63, \mathrm{~S}=$ $28.74 ; n=86$ ). This is in contrast to the findings of Lesch et al. [1996] and a large replication sample of mostly women (primarily sibling pairs) collected by the same group that found higher levels of neuroticism in individuals with the s-allele [Greenberg et al., 2000]. Other studies have failed to replicate the association [Flory et al., 1999; Jorm et al., 2000].

Table I. Mean NEO-FFI Personality Traits Scores and Standard Deviations for Groups Defined by 5-HTTLPR Genotype*

\begin{tabular}{|c|c|c|c|c|c|c|c|c|}
\hline \multirow[b]{2}{*}{ Genotype } & \multicolumn{4}{|c|}{ NEO-FFI scores by genotype } & \multirow[b]{2}{*}{$\mathrm{F}$} & \multirow[b]{2}{*}{$S-L$} & \multirow[b]{2}{*}{$P$} & \multirow[b]{2}{*}{$P^{\mathrm{a}}$} \\
\hline & $1 / 1$ (group L) & $1 / \mathrm{s}$ & $\mathrm{s} / \mathrm{s}$ & 1/s \& s/s (group S) & & & & \\
\hline Number per group & 24 & 45 & 17 & 62 & & & & \\
\hline Neuroticism & $28.63 \pm 8.60$ & $29.20 \pm 9.39$ & $27.53 \pm 6.76$ & $28.74 \pm 8.73$ & 0.003 & 0.11 & 0.96 & 0.44 \\
\hline Extraversion & $41.04 \pm 6.44$ & $41.98 \pm 6.08$ & $42.41 \pm 5.47$ & $42.10 \pm 5.88$ & 0.59 & 1.06 & 0.47 & 0.41 \\
\hline Openness & $34.54 \pm 5.01$ & $38.29 \pm 6.86$ & $38.47 \pm 4.53$ & $38.34 \pm 6.27$ & 7.04 & 3.80 & 0.01 & 0.005 \\
\hline Agreeableness & $45.13 \pm 4.79$ & $44.71 \pm 6.47$ & $46.71 \pm 6.88$ & $45.26 \pm 6.59$ & 0.008 & 0.13 & 0.93 & 0.90 \\
\hline Conscientiousness & $46.92 \pm 8.14$ & $43.69 \pm 8.15$ & $48.06 \pm 6.27$ & $44.89 \pm 7.88$ & 1.13 & -2.03 & 0.29 & 0.17 \\
\hline
\end{tabular}

*Mean scores and standard deviations for the five major traits measured by the NEO-FFI stratified by genotype and group. $\mathrm{F}=$ one-way ANOVA statistics; S - L = mean score for S-genotype group minus mean score for L-genotype group; P = two-tailed significance.

a Two-tailed significance level after controlling for sex and father's alcoholism status in a general linear model. 
Table II. Observed 5-HTTLPR Genotypes and Frequencies of s-Allele for Fathers Categorized by Alcoholism Subtype*

\begin{tabular}{lrrrrr}
\hline & $\mathrm{s} / \mathrm{s}$ & $\mathrm{l} / 1$ & $\mathrm{l} / \mathrm{s}$ & $N$ & $\mathrm{~F}(\mathrm{~s})$ \\
\hline AAL & 4 & 10 & 3 & 17 & 0.53 \\
NAAL & 4 & 6 & 4 & 16 & 0.50 \\
Control & 2 & 6 & 5 & 13 & 0.38 \\
Total & 10 & 22 & 12 & 44 & 0.48 \\
\hline
\end{tabular}

${ }^{*} \mathrm{AAL}=$ antisocial alcoholic; NAAL = nonantisocial alcoholic; Control $=$ nonalcoholic.

Father's genotype is not associated with his alcoholism status $($ Fisher exact statistic $=2.24 ; P=0.73)$.

It may be that differences between the sample populations can account for such inconsistencies. The sample analyzed in the present study, while not a treatment population, its diagnostic characteristics both for alcoholism and comorbid psychiatric disorders clearly establish it as a clinical one [Zucker et al., 2000].

In this study, 5-HTTLPR genotype groups differed on the personality trait of openness. The association was statistically significant only among men; although among women, the pattern was in the same direction (i.e., higher mean scores for individuals with an s-allele). Because mean platelet 5-HTT binding availability was lower in individuals with an s-allele, these results suggest that the effect of 5-HTTLPR on openness may be partially mediated through 5-HTT binding availability and moderated by gender. However, in the present study, we could not fully support this mediational hypothesis because the correlation between [ ${ }^{125}$ I]RTI-55 binding and openness was not significant $(n=33 ; r=-0.18 ; P=0.31)$, but this may due to low statistical power. Testing mediational hypotheses between genes, biochemical, or physiological measures and behavior may prove to be an important approach to understanding heredity-behavior relations.

In the study by Greenberg et al. [2000], the pattern of mean openness scores in their new sample is similar to the one we report, although the differences were not statistically significant. This pattern is not seen in their combined sample. The samples that Greenberg et al. [2000] added are those reported by Lesch et al. [1996], who appear to be younger, more ethnically diverse, better educated, and perhaps contain different distribution of sexual orientation than our study population. It is possible that such differences account for the observed discrepancies.

Higher openness scores are related to a history of depression, and this effect is over and above the association between neuroticism and depression [Wolfenstein and Trull, 1997]. It may be that the s-allele increases risk for depression through either neuroticism or openness. That the mean openness scores for those with s/s and 1/s genotypes are different from those with the VI genotype in the present study provides some measure of confidence because it mirrors the pattern seen for $\left[{ }^{125} \mathrm{I}\right]$ RTI-55 binding. The $P$ value of the association of 5-HTTLPR genotype and openness when controlling for sex and father's alcoholism status $(P=0.005)$ survives Bonferroni correction for the 10 comparisons conducted for genotype and NEO-FFI scores. However, further confidence will require replication. Until then, these findings should be regarded as preliminary and interpreted with caution.

Father's alcoholism diagnosis or alcoholism subtype was not associated with 5-HTTLPR genotype. This is consistent with findings from the COGA group [Edenberg et al., 1998]. However, other groups have reported associations between 5-HTTLPR and alcohol use disorders in other populations (e.g., dependence in French [Hammoumi et al., 1999], antisocial alcoholism in Finnish [Hallikainen et al., 1999], and early-onset alcoholism in Japanese [Ishiguro et al., 1999]). Allelic variation at 5-HTTLPR has also been found associated with low response to alcohol [Schuckit et al., 1999] and high ethanol tolerance [Turker et al., 1998]. Taken together, these conflicting reports (and others) highlight the complexity inherent in the study of psychiatric genetics [Stoltenberg and Burmeister, 2000] and suggest that in different environments and populations the pattern of 5-HTTLPR effects may be different. In other words, genotype $\times$ environment and/or genotype $\times$ genotype interactions may exist for 5-HTTLPR effects on alcoholism.

In summary, this study replicated the dominance pattern of the s-allele for reduced 5-HTTLPR function as indexed by platelet [ $\left.{ }^{125} \mathrm{I}\right] \mathrm{RTI}-55$ binding. Results did not support for the association of 5-HTTLPR genotype with neuroticism or alcoholism; however, increased mean openness scores were associated with the s-allele.

\section{Acknowledgments}

The authors thank Zhi-Ying Yang for expert technical assistance. This research was supported by NIAAA grants 5 R01 AA07065 (to R.A.Z. and H.E.F.), 5 K01 AA00295 (to S.F.S.), and a postdoctoral training fellowship to UCLA Drug Abuse Research Center (to G.R.T.). Some of the results of this study were obtained by using the program package SAGE, which is supported by a U.S. Public Health Service Resource Grant (1 P41 RR03655) from the National Center for Research Resources. A preliminary analysis of a portion of these data was presented at the Second International Meeting on the Genetic Epidemiology of Complex Traits in Cambridge, England, April 1-3, 2000 (S.F.S.).

\section{References}

American Psychiatric Association. 1987. Diagnostic and statistical manual of mental disorders. Washington, DC: American Psychiatric Association.

Anderson GM, Young JG, Cohen DJ, Schlicht KR, Patel N. 1981. Liquid-chromatographic determination of serotonin and tryptophan in whole blood and plasma. Clin Chem 27:775-776.

Bengel D, Greenberg BD, Cora-Locatelli G, Altemus M, Heils A, Li Q, Murphy DL. 1999. Association of the serotonin transporter promoter regulatory region polymorphism and obsessive-compulsive disorder. Mol Psychiatry 4:463-466.

Collier DA, Stober G, Li T, Heils A, Catalano M, Di Bella D, Arranz MJ, Murray KM, Vallada HP, Bengel D, Muller CR, Roberts GW, Smeraldi E, Kirov G, Sham P, Lesch KP. 1996. A novel functional polymorphism within the promoter of the serotonin transporter gene: Possible role in susceptibility to affective disorders. Mol Psychiatry 1:453-460.

Cook EH Jr., Courchesne R, Lord C, Cox NJ, Yan S, Lincoln A, Haas R, Courchesne E, Leventhal BL. 1997. Evidence of linkage between the serotonin transporter and autistic disorder. Mol Psychiatry $2: 247-250$.

Costa PT, McCrae RR. 1992. Revised NEO Personality Inventory (NEO- 
PI-R) and NEO Five Factor Inventory (NEO-FFI) professional manual. Odessa, FL: Psychological Assessment Resources.

Edenberg HJ, Reynolds J, Roller DL, Begleiter H, Bucholz KK, Conneally PM, Crowe R, Goate A, Hesselbrock V, Li TK, Nurnberger JI Jr., Porjesz B, Reich T, Rice JP, Schuckit M, Tischfield JA, Foroud T. 1998. A family-based analysis of whether the functional promoter alleles of the serotonin transporter gene HTT affect the risk for alcohol dependence. Alcohol Clin Exp Res 22:1080-1085.

Feighner JP, Robins E, Guze SB, Woodruff RA Jr., Winokur G, Munoz R. 1972. Diagnostic criteria for use in psychiatric research. Arch Gen Psychiatry 26:57-63.

Fitzgerald HE, Zucker RA, Yang H-Y. 1995. Developmental systems theory and alcoholism: Analyzing patterns of variation in highrisk families. Psychol Addict Behav 9:8-22.

Flory JD, Manuck SB, Ferrell RE, Dent KM, Peters DG, Muldoon MF. 1999. Neuroticism is not associated with the serotonin transporter (5-HTTLPR) polymorphism. Mol Psychiatry 4:93-96.

Greenberg BD, Tolliver TJ, Huang SJ, Li Q, Bengel D, Murphy DL. 1999. Genetic variation in the serotonin transporter promoter region affects serotonin uptake in human blood platelets. Am J Med Genet 88:83-87.

Greenberg BD, Li Q, Lucas FR, Hu S, Sirota LA, Benjamin J, Lesch KP, Hamer D, Murphy DL. 2000. Association between the serotonin transporter promoter polymorphism and personality traits in a primarily female population sample. Am J Med Genet 96:202-216.

Gustavsson JP, Nothen MM, Jonsson EG, Neidt H, Forslund K, Rylander G, Mattila-Evenden M, Sedvall GC, Propping P, Asberg M. 1999. No association between serotonin transporter gene polymorphisms and personality traits. Am J Med Genet 88:430-436.

Hallikainen T, Saito T, Lachman HM, Volavka J, Pohjalainen T, Ryynanen OP, Kauhanen J, Syvalahti E, Hietala J, Tiihonen J. 1999. Association between low activity serotonin transporter promoter genotype and early onset alcoholism with habitual impulsive violent behavior. Mol Psychiatry 4:385-388.

Hammoumi S, Payen A, Favre JD, Balmes JL, Benard JY, Husson M, Ferrand JP, Martin JP, Daoust M. 1999. Does the short variant of the serotonin transporter linked polymorphic region constitute a marker of alcohol dependence? Alcohol 17:107-112.

Hanna GL, Himie JA, Curtis GC, Koram DQ, Veenstra-VanderWeele J, Leventhal BL, Cook EH Jr. 1998. Serotonin transporter and seasonal variation in blood serotonin in families with obsessive-compulsive disorder. Neuropsychopharmacology 18:102-111.

Heils A, Teufel A, Petri S, Stober G, Riederer P, Bengel D, Lesch KP. 1996. Allelic variation of human serotonin transporter gene expression. J Neurochem 66:2621-2624.

Heils A, Mossner R, Lesch KP. 1997. The human serotonin transporter gene polymorphism: Basic research and clinical implications. J Neural Transm 104:1005-1014.

Ishiguro H, Saito T, Akazawa S, Mitushio H, Tada K, Enomoto M, Mifune H, Toru M, Shibuya H, Arinami T. 1999. Association between drinking-related antisocial behavior and a polymorphism in the serotonin transporter gene in a Japanese population. Alcohol Clin Exp Res 23: 1281-1284.

Jorm AF, Prior M, Sanson A, Smart D, Zhang Y, Easteal S. 2000. Association of a functional polymorphism of the serotonin transporter gene with anxiety-related temperament and behavior problems in children: A longitudinal study from infancy to the mid-teens. Mol Psychiatry 5:542-547.

Lesch KP, Bengel D, Heils A, Sabol SZ, Greenberg BD, Petri S, Benjamin J, Muller CR, Hamer DH, Murphy DL. 1996. Association of anxiety-related traits with a polymorphism in the serotonin transporter gene regulatory region. Science 274:1527-1531.

Little KY, Kirkman JA, Carroll FI, Breese GR, Duncan GE. 1993. [ $\left.{ }^{125} \mathrm{I}\right]$ RTI55 binding to cocaine-sensitive dopaminergic and serotonergic uptake sites in the human brain. J Neurochem 61:1996-2006.

Little KY, McLaughlin DP, Zhang L, Livermore CS, Dalack GW, McFinton PR, DelProposto ZS, Hill E, Cassin BJ, Watson SJ, Cook EH. 1998. Cocaine, ethanol, and genotype effects on human midbrain serotonin transporter binding sites and mRNA levels. Am J Psychiatry 155:207-213.
Mazzanti CM, Lappalainen J, Long JC, Bengel D, Naukkarinen H, Eggert M, Virkkunen M, Linnoila M, Goldman D. 1998. Role of the serotonin transporter promoter polymorphism in anxiety-related traits. Arch Gen Psychiatry 55:936-940.

Poon E, Ellis DA, Fitzgerald HE, Zucker RA. 2000. Intellectual, cognitive, and academic performance among sons of alcoholics, during the early school years: Differences related to subtypes of familial alcoholism. Alcohol Clin Exp Res 24:1020-1027.

Puttier LI, Zucker RA, Fitzgerald HE, Bingham CR. 1998. Behavioral outcomes among children of alcoholics during the early and middle childhood years: Familial subtype variations. Alcohol Clin Exp Res 22: 1962-1972.

Robins LN, Helzer JE, Croughan J, Ratcliff K. 1981. National Institute of Mental Health diagnostic interview schedule. Arch Gen Psych 38:381-389.

SAGE. 1998. Statistical analysis for genetic epidemiology. Department of Epidemiology and Biostatistics, Rammelkamp Center for Education and Research, MetroHealth Campus, Case Western Reserve University, Cleveland, $\mathrm{OH}$.

Sander T, Harms H, Lesch KP, Dufeu P, Kuhn S, Hoehe M, Rommelspacher H, Schmidt LG. 1997. Association analysis of a regulatory variation of the serotonin transporter gene with severe alcohol dependence. Alcohol Clin Exp Res 21:1356-1359.

Schuckit MA, Mazzanti C, Smith TL, Ahmed U, Radel M, Iwata N, Goldman D. 1999. Selective genotyping for the role of 5-HT2A, 5HT2C, and GABA alpha 6 receptors and the serotonin transporter in the level of response to alcohol: A pilot study. Biol Psychiatry 45:647-651.

Stoltenberg SF, Burmeister M. 2000. Recent progress in psychiatric genetics - Some hope but no hype. Hum Mol Genet 9:927-935.

Turker T, Sodmann R, Goebel U, Jatzke S, Knapp M, Lesch KP, Schuster R, Schutz H, Weiler G, Stober G. 1998. High ethanol tolerance in young adults is associated with the low-activity variant of the promoter of the human serotonin transporter gene. Neurosci Lett 248:147-150.

Twitchell GR, Hanna GL, Cook EH, Fitzgerald HE, Little KY, Zucker RA. 1998. Overt behavior problems and serotonergic function in middle childhood among male and female offspring of alcoholic fathers. Alcohol Clin Exp Res 22:1340-1348.

Twitchell GR, Hanna GL, Cook EH, Fitzgerald HE, Zucker RA. 2000. Serotonergic function, behavioral disinhibition, and negative affect in children of alcoholics: The moderating effects of puberty. Alcohol Clin Exp Res 24:972-979.

Twitchell GR, Hanna GL, Cook EH, Stoltenberg SF, Fitzgerald HE, Zucker RA. 2001. Serotonin transporter promoter polymorphism genotype is associated with behavioral disinhibition and negative affect in children of alcoholics. Alcohol Clin Exp Res 25:953-959.

Wolfenstein M, Trull TJ. 1997. Depression and openness to experience. J Pers Assess 69:614-632.

Wong MM, Zucker RA, Puttier LI, Fitzgerald HE. 1999. Heterogeneity of risk aggregation for alcohol problems between early and middle childhood: Nesting structure variations. Dev Psychopathol 11:727-744.

Zucker RA. 1987. The four alcoholisms: A developmental account of the etiologic process. In: Rivers PC, editor. Alcohol and addictive behaviors: Nebraska symposium on motivation, Lincoln, NE: University of Nebraska Press, p 27-83.

Zucker RA, Ellis DA, Bingham CR, Fitzgerald HE. 1996. The development of alcoholic subtypes: Risk variation among alcoholic families during the early childhood years. Alcohol Health Res World 20:46-54.

Zucker RA, Ellis DA, Fitzgerald HE, Bingham CR, Sanford DP. 1997. Other evidence for at least two alcoholisms: II, Life course variation in antisociality and heterogeneity of alcoholic outcome. Dev Psychopathol 8:831-848.

Zucker RA, Fitzgerald HE, Refior SK, Puttier LI, Pallas DM, Ellis DA. 2000. The clinical and social ecology of childhood for children of alcoholics: Description and implications for a differentiated social policy. In: Fitzgerald HE, Lester BM, Zuckerman BS, editors. Children of addiction. New York: Routledge Falmer. p 109-142. 